\title{
Water quality assessment and physicochemical parameters of groundwater in District Hapur, Uttar Pradesh, India
}

\author{
Udit Mohan $^{1}$, Randhir Singh ${ }^{1}$, Prem Singh ${ }^{2}$
}

Received: 08.07.2013

Revised: 11.09.2013

Accepted: 20.10.2013

\begin{abstract}
The present study investigation of the ground water contamination of Hapur district (U.P.), India has been carried out. The ground water samples were collected from different locations from hand pumps mark II in Hapur district.Water Quality Index (WQI) of drinking water has been assessed by using various physicochemical \& biological parameters for the ground wateranalysis. Water samples were analysed using various physicochemical and biological parameters such as pH, Electrical Conductivity, Total Dissolved Solid, Total Hardness, Chloride, Fluoride, Nitrate, Sulphate, Total Acidity, Total Alkalinity, Chemical Oxygen Demand (COD), Biological Oxygen Demand (BOD) and Dissolved Oxygen (DO)etc. and the results compared with the standards given by WHO, ICMR and BISThe correlation between different parameters was also assessed. The average values of physicochemical and biological parameters were observed as pH 7.86, Electrical conductivity $1206.67 \mathrm{mmhos} / \mathrm{cm}$, TH $734.17 \mathrm{mg} / \mathrm{l}$, acidity $352.08 \mathrm{mg} / \mathrm{l}$, total alkalinity $464.17 \mathrm{mg} / \mathrm{l}$, TDS $645.17 \mathrm{mg} / \mathrm{l}$, chloride $85.50 \mathrm{mg} / \mathrm{l}$, fluoride $0.77 \mathrm{mg} / \mathrm{l}$, nitrate $45.99 \mathrm{mg} / \mathrm{l}$, sulphate $160.39 \mathrm{mg} / \mathrm{l}, \mathrm{COD} 12.79 \mathrm{mg} / \mathrm{l}, \mathrm{DO} 4.08$ $\mathrm{mg} / \mathrm{l}$ and BOD $1.99 \mathrm{mg} / \mathrm{l}$ respectively. The WQI of different blocks of district Hapur reveals that the water quality is poor for drinking and other activities.
\end{abstract}

Keyword: Physicochemical parameter, WQI, correlation coefficient, ground water quality

\section{Introduction}

The indiscriminate use of chemical, fertilizers, pesticides and industrial effluents thronging in the ground water and mixing in the water level has become a serious environmental and public health problem everywhere in India and as a whole in the world. The urbanization and rapid population growth has also produced a vast amount of health hazards (Degremont, G.1991). The waste is often piled as high as the industrial unit allows. Most commonly reported danger to human health from the landfill is from the use of groundwater that has been contaminated by leachate. Water quality performs important role for all living beings. Ground water quality has become an essential water resources issue due to rapid increase of population, rapid industrialization, unplanned urbanization,

\section{Author's Address}

${ }^{1}$ Department of Chemistry, Gurukula Kangri University, Haridwar (Uttarakhand), India

${ }^{2}$ Project Directorate for Farming Systems Research, Modipuram, Meerut - 250110 (UP), India

Email: aadiudit@gmail.com flow of pollution from upland to lowland, and too much use of fertilizers, pesticides in agriculture (Jameel, A. 1998). Ground water is one of the earth's widely distributed, renewable and most important resources. It is generally considered least polluted compared to other inland water resources, but studies indicate that ground water is not absolutely free from pollution though it is likely to be free from suspended solids (Mishra et al. 2003). Several million of theworld's population is suffering from water-bornediseases due to consumption of contaminatedwater with $>250$ million such new cases each year (Barabas 1986). The major problem with the ground water is that once contaminated, it is difficult to restore its quality (Goel, 2000). Hence there is a great need for the protection and management of ground water quality. It is well known that no straight forward reasons can be advanced for the deterioration of water quality as it is dependent on several water quality parameters. Some of these parameters constitutea risk to human health, others affect the aesthetic quality of the water supplied, and others 
relate totreatment issues (Ratnayaka et al. 2009).The strong correlations amongst different parameters and combined effect of their interrelatedness indicates the groundwater quality. The quality in the Industrial areas is determined by measuring the concentration of some physicochemical parameters and comparing those with drinking water standards. As it is well known that the use of water is being carried out for consumption for various activities. (Khanna et al. 2005 and Miller, 1985). Many studies on groundwater quality with respectto drinking and irrigation purposes have been carriedout in the different parts of India (Sunitha et al. 2005; Subba Rao 2006; Giridharanet al. 2008; Das et al.2010; Krishna Kumar et al. 2011; SarathPrasanthetal. 2012).The developed regression equations for the parameters having significant correlation coefficients can be successfully used to estimate the concentration of other constituents. A systematic study of correlation and regression coefficients of the water quality parameters not only helps to assess the overall water quality but also to quantify relative concentration of various pollutants in water and provide necessary clues for implementation of rapid water quality management programmes. In the present study, an attempt has been made to evaluate the quality of ground water in the area for correlation and regression studies of various physico-chemical parameters.

\section{Material and methods}

Study area: Hapur district is located at $28.72^{\circ} \mathrm{N}$ $77.78^{\circ} \mathrm{E}$ covering an area of 660 sq. miles. It has an average elevation of 213 meters (699 feet). Hapur district comprises four blocks Hapur, Garhmukteshwar, Dhaulanaand Simbhawali (Table 1). Many small growing Industries are established in different blocks of district like sugar mills, bottling plant, crashers, Paper and pulp factories etc. The treated and untreated contaminated effluent from these Industries is being discharged into the ground which is absorbed by the soil and thus reaches the ground water table and contaminate it. Once it is contaminated, it is difficult to restore the original quality of water so it is our duty to assess the quality of groundwater for consuming in various activities for mankind.

Collection of samples: In the present study 28 water samples were collected from different blocks, Hand pumps (Mark II) of Hapur district (Figure 1). The samples were collected in pre-cleaned and well-dried sterilized screw-capped polyethylene bottles $(2.5 \mathrm{~L})$ with necessary precautions of standard method according to APHA and WHO. The sample bottles were labelled with collection details to minimise any errors. The collected samples were stored in an icebox and brought to laboratory for determining both physical chemical and biological parameters.

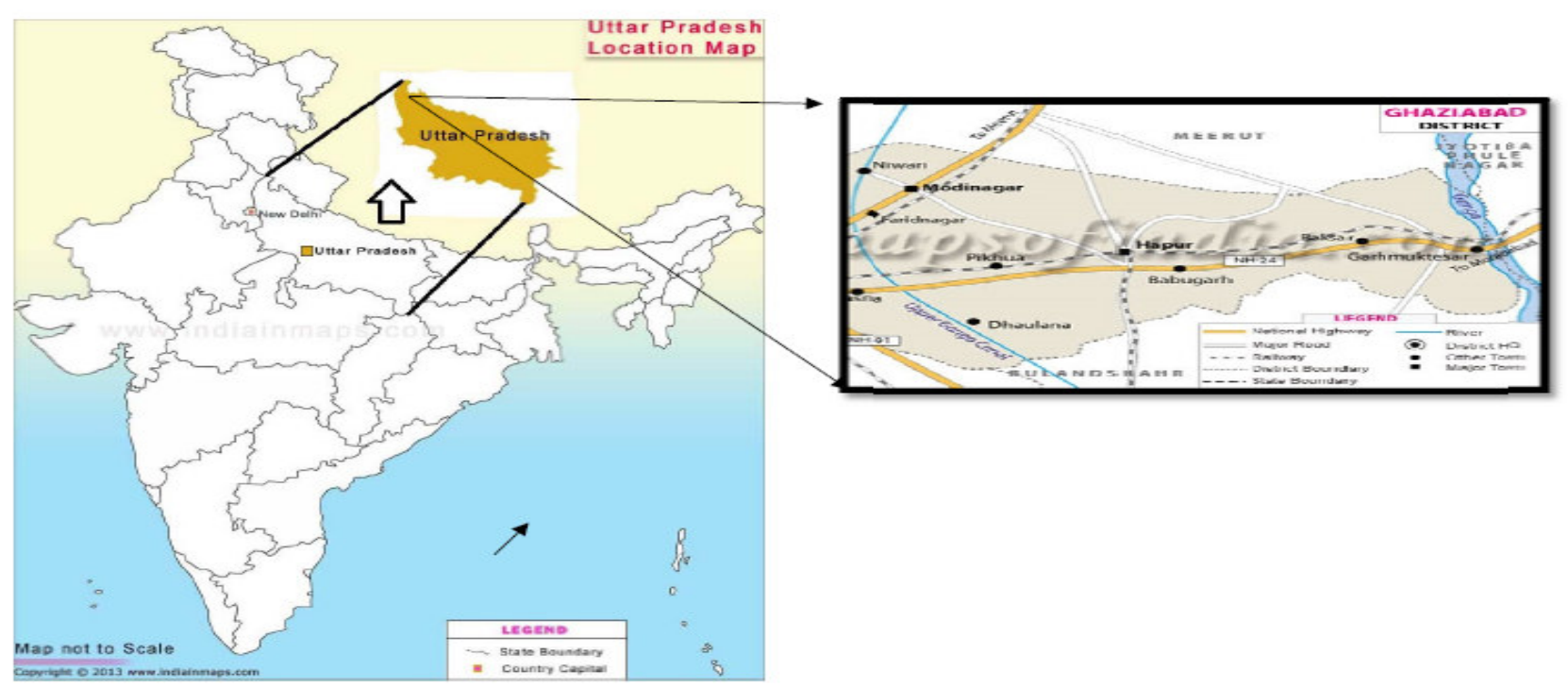

Fig. 1: Map showing different sampling sites 
Water quality assessment and physicochemical parameters

I'able1: GIS points of water collection

\begin{tabular}{lllll}
\hline Block & Location (n) & Latitude & Longitude & Height \\
\hline \multirow{5}{*}{ Hapur } & Ahmad Nagar(3) & $28^{0} 38^{\prime} 25 \mathrm{~N}$ & $77^{0} 51^{\prime} 06 \mathrm{E}$ & 213 \\
\cline { 2 - 5 } & Babugarh(2) & $28^{0} 43^{\prime} 19 \mathrm{~N}$ & $77^{0} 50^{\prime} 50 \mathrm{E}$ & 217 \\
\cline { 2 - 5 } & Hapur railway station (1) & $28^{0} 44^{\prime} 22 \mathrm{~N}$ & $77^{0} 46^{\prime} 51 \mathrm{E}$ & 219 \\
\hline \multirow{5}{*}{ Dhaulana } & Dhaulana (3) & $28^{0} 45^{\prime} 38 \mathrm{~N}$ & $77^{0} 48^{\prime} 21 \mathrm{E}$ & 221 \\
\cline { 2 - 5 } & Shyamnagar(2) & $28^{0} 45^{\prime} 35 \mathrm{~N}$ & $77^{0} 49^{\prime} 34 \mathrm{E}$ & 218 \\
\cline { 2 - 5 } Garh & Khera(3) & $28^{0} 46^{\prime} 16 \mathrm{~N}$ & $77^{0} 46^{\prime} 25 \mathrm{E}$ & 217 \\
\cline { 2 - 5 } & GarhRailway station (2) & $28^{0} 46^{\prime} 55 \mathrm{~N}$ & $77^{0} 04^{\prime} 06 \mathrm{E}$ & 218 \\
\cline { 2 - 5 } & Salarpur(2) & $28^{0} 43^{\prime} 43 \mathrm{~N}$ & $77^{0} 05^{\prime} 06 \mathrm{E}$ & 217 \\
\cline { 2 - 5 } Simbhawali & Dehra Rampur (2) & $28^{0} 43^{\prime} 13 \mathrm{~N}$ & $77^{0} 04^{\prime} 06 \mathrm{E}$ & 214 \\
\cline { 2 - 5 } & SimbhawaliRailway station (3) & $28^{0} 46^{\prime} 05 \mathrm{~N}$ & $77^{0} 59^{\prime} 06 \mathrm{E}$ & 220 \\
\cline { 2 - 5 } & Baksar(3) & $28^{0} 45^{\prime} 43 \mathrm{~N}$ & $78^{0} 01^{\prime} 06 \mathrm{E}$ & 219 \\
\cline { 2 - 5 } & Athseni(2) & $28^{0} 46^{\prime} 53 \mathrm{~N}$ & $78^{0} 02^{\prime} 06 \mathrm{E}$ & 217 \\
\hline
\end{tabular}

$\mathrm{n}=$ no of samples collected

Methods: AR grade chemicals were used for this studies. Double distilled water was used for the preparation of all the reagents and solutions. Glasswares were cleaned with Thomas Baker Thromaklin liquid soap followed by distilled water and dries in the oven before the analysis. (APHA, 2005; BIS 1998).The $\mathrm{pH}$ and Electrical Conductivity were measured by using Systronics digital pH meter (model 335) and Systronics digital conductivity meter (model 304). TDS was determined by using Century TDS meter. Total Hardnesswas measured by EDTA titration method. The total alkalinity ofwater is determined by titration with a strong acid to methyl orange. Chloride was measured volumetrically by silver nitrate titrimetric method using potassium chromate as indicator and was calculated in terms of $\mathrm{mg} / \mathrm{L}$. Sulphate was measured by Gravimetric method using Barium chloride as precipitating agent. Nitrate was measured by the spectrophotometric method. DO was measured by Winkler's titration method. COD was measured by closed reflux method and BOD was measured by the 5 days incubation method. The physicochemical analysis was carried out according to standard methods.

Water Quality Index (WQI): WQI was estimated according to the formula (Mahuya et al., 2003) as given below.

\section{WQI = Antilog $\left(\sum W n \log Q n\right)$}

Where, $\mathrm{Wn}=$ weightage of the parameter in the sample $=\mathrm{K} / \mathrm{Sn}$

$\mathrm{K}=$ constant $=1 /$

$(1 / \mathrm{S} 1+1 / \mathrm{S} 2+1 / \mathrm{S} 3 \ldots \ldots \ldots \ldots+1 / \mathrm{Sn})$

$\mathrm{Sn}=$ standard values for different water quality parameter.

$\mathrm{Qn}=$ water quality rating $=100(\mathrm{Vn}-\mathrm{Vi}) /(\mathrm{Sn}-\mathrm{Vi})$

$\mathrm{Vn}=$ observed value, $\mathrm{Vi}=$ ideal value $=7.0$ for $\mathrm{pH}$, 14.6For DO, 0 for other parameters.

The water quality of different sites and has been rated according to the WQI (table 2).

Table 2: The water quality of different sites has been rated According to the WQI as given below

\begin{tabular}{rc}
\hline WQI & Water quality rating \\
\hline $\mathbf{0}-\mathbf{4 4}$ & Poor \\
$\mathbf{4 5 - 6 4}$ & Marginal \\
$\mathbf{6 5}-\mathbf{7 9}$ & Fair \\
$\mathbf{8 0 - 8 8}$ & Good \\
$\mathbf{8 9 - 9 4}$ & Very good \\
$\mathbf{9 5 - 1 0 0}$ & Excellent \\
\hline
\end{tabular}




\section{Results and discussion}

The results of various physico-chemical parameters like $\mathrm{pH}$, electrical conductivity, total dissolved solids, total hardness, acidity, total Alkalinity, chlorides, fluorides, sulphates, nitrates, chemical oxygen demand, dissolved oxygen and biochemical oxygen demand are shown in Table 4 while correlation and coefficient are given in table 5. The appearance of all the tested samples of ground water have no odour and taste. The $\mathrm{pH}$ studies showed that the $\mathrm{pH}$ of the water samples was range from7.62 - 8.00 (mean 7.86) which is within the permissible limits (BIS 1998 and WHO 1997). Chaurasia and Pandey (2007) have also reportedslightly basic $\mathrm{pH}$ of water in Faizabad region.The electrical conductivity of water samples ranged from $530-2080 \mathrm{mmho} / \mathrm{cm}$. However the prescribed limit is $1000 \mathrm{mmho} / \mathrm{cm}$ according to WHO for drinking water and the mean 1206 $\mathrm{mmho} / \mathrm{cm}$ which is higher than the BIS and WHO (1997). Few water samples possess higher values than the permissible limits may be due to presence of dissolved inorganic substances. The TDS in water comprises of inorganic salts and small amounts of organic matter which varies from 380$1221 \mathrm{mg} / \mathrm{l}$. Water with higher solid content indicated that the groundwater is of poor potability and may induce an unfavourable physiological reaction(Shankar et al. 2008). The desirable limit of TDS for drinking water is $500 \mathrm{mg} / \mathrm{l}$. The total hardness ranged between 307- $786.6 \mathrm{mg} / \mathrm{l}$. and was higher than the prescribed standard value $(500 \mathrm{mg} /$ 1). Increase in value pertains to the excess presence of the salts of $\mathrm{Ca}$ and $\mathrm{Mg}$. Chlorides, which have been associated with pollution as an index were found in the range of $14.2-227.2 \mathrm{mg} / \mathrm{l}$. The concentration of chlorideion in the present observations was within the higher range of desirable limit of WHO $(250 \mathrm{mg} / \mathrm{l})$. The chloride limits have been laid down primarily from taste view point.However, no adverse health effects on human being have been reported by the use of water havinghigh chloride concentrations (Jain et al. 2010). The phenolphthalein alkalinity was found to be absent in all the samples analysed and the methyl orange alkalinity varied from $315-615 \mathrm{mg} / \mathrm{l}$. This indicates the absence of hydroxyl alkalinity and the presence of carbonate and bicarbonates. However, the values of all the sampling sites were quite higher than the desirable limits $(120 \mathrm{mg} / \mathrm{l})$. According to Sharma and Rao (1997) the value of hardness and fluoride is higher than the permissible limits. The fluoride content of all the sampling sites ranged between $0.46-0.97 \mathrm{mg} / \mathrm{l}$, which were below the recommended limits (Sharma \& Rao1997). Sulphate content ranged from $71.98-372.47 \mathrm{mg} / \mathrm{l}$, whereas the permissible limit for sulphates is 200 $\mathrm{mg} / \mathrm{l}$. The level of nitrates in the ground water ranged between $16.10-74.89 \mathrm{mg} / \mathrm{l}$. Nitrate concentration more than the recommended value (45 mg/l) was observed on five sampling sites. The amount of DO ranged between $2.67-5.87 \mathrm{mg} / \mathrm{l}$ in water of all nine sampling stations and was less in comparison to minimum DO recommended by WHO (Table 3).

Table-3: Comparison of ground water quality with drinking water standards

\begin{tabular}{lcccc}
\hline Parameter & WHO & BIS & ICMR & Present study report \\
\hline PH & $6.5-9.2$ & $6.5-8.5$ & $6.5-8.5$ & $7.62-8.00$ \\
EC, mmho/cm & 300 & - & - & $530-2080$ \\
TDS & 500 & 500 & $500-1500$ & $380-1221$ \\
Total Hardness & - & 200 & 300 & $590-900$ \\
Chloride & 200 & 250 & 250 & $14.20-227.20$ \\
Fluoride & 1.5 & 1 & & $0.46-0.97$ \\
Total Acidity & - & - & - & $185-565$ \\
Total Alkalinity & - & 200 & - & $315-615$ \\
Nitrate & 45 & 45 & 200 & $16.10-74.89$ \\
Sulphate & 200 & 200 & - & $71.98-372.47$ \\
COD & 10 & - & - & $7.92-25.74$ \\
DO & $>5$ & - & - & $2.67-5.87$ \\
BOD & $<5$ & - & & $1.06-2.90$ \\
\hline
\end{tabular}


Water quality assessment and physicochemical parameters

Table 4: Comparison of various physico-chemical parameters of different blocks

\begin{tabular}{|c|c|c|c|c|c|c|c|c|c|}
\hline Parameters & Hapur & Dhaulana & Simbhawali & Garh & Mean & Median & $\begin{array}{l}\text { Std } \\
\text { error }\end{array}$ & $\begin{array}{l}95 \% \\
\text { conf }\end{array}$ & $\begin{array}{l}99 \% \\
\text { conf }\end{array}$ \\
\hline pH & $7.62-7.85$ & $7.87-8.00$ & $7.70-7.93$ & $7.85-7.96$ & $\begin{array}{l}7.86 \\
\pm 0.11\end{array}$ & 7.88 & 0.03 & 0.07 & 0.10 \\
\hline $\begin{array}{l}\text { EC } \\
(\mu \mathrm{mhos} / \mathrm{cm})\end{array}$ & $1060-1490$ & $720-1270$ & $1150-1790$ & $530-2080$ & $\begin{array}{l}1206.67 \\
\pm 440.63\end{array}$ & 1175.00 & 127.2 & 279.97 & 395.09 \\
\hline $\begin{array}{l}\text { TH } \\
(\mathrm{mg} / \mathrm{l})\end{array}$ & $750-830$ & $620-710$ & $630-750$ & $590-880$ & $\begin{array}{l}734.17 \\
\pm 99.59\end{array}$ & 730.00 & 28.75 & 63.28 & 89.29 \\
\hline $\begin{array}{l}\text { Acidity } \\
\text { (mg/l) }\end{array}$ & $385-540$ & $270-390$ & $280-565$ & $280-543$ & $\begin{array}{l}352.08 \\
\pm 116.57\end{array}$ & 327.50 & 33.65 & 74.07 & 104.52 \\
\hline $\begin{array}{l}\text { TA } \\
(\mathrm{mg} / \mathrm{l})\end{array}$ & $375-475$ & $315-485$ & $340-600$ & $395-615$ & $\begin{array}{l}464.17 \\
\pm 96.81\end{array}$ & 465.00 & 27.95 & 61.51 & 86.80 \\
\hline $\begin{array}{l}\text { TDS } \\
(\mathrm{mg} / \mathrm{l})\end{array}$ & $86.80-263.18$ & $121.91-162.49$ & $133.11-156.53$ & $71.98-160.49$ & $\begin{array}{l}645.17 \\
\pm 263.08\end{array}$ & 601.00 & 75.94 & 167.16 & 235.89 \\
\hline $\begin{array}{l}\mathrm{Cl} \\
(\mathrm{mg} / \mathrm{l})\end{array}$ & $65.39-74.89$ & $19.06-25.46$ & $43.63-72.43$ & $16.10-38.35$ & $\begin{array}{l}85.50 \\
\pm 65.83\end{array}$ & 74.55 & 19.00 & 41.83 & 59.03 \\
\hline $\begin{array}{l}\mathbf{F} \\
(\mathrm{mg} / \mathrm{l})\end{array}$ & $102.95-227.20$ & 28.4- 99.4 & $14.2-92.3$ & $31.5-134.9$ & $\begin{array}{l}0.77 \\
\pm 0.15\end{array}$ & 0.82 & 0.04 & 0.10 & 0.14 \\
\hline $\begin{array}{l}\mathrm{NO}_{2} \\
(\mathrm{mg} / \mathrm{l})\end{array}$ & $0.83-0.88$ & $0.46-0.52$ & $0.76-0.84$ & $0.64-0.97$ & $\begin{array}{l}45.99 \\
\pm 22.97\end{array}$ & 40.99 & 6.63 & 14.60 & 20.60 \\
\hline $\begin{array}{l}\mathrm{SO}_{4} \\
(\mathrm{mg} / \mathrm{l})\end{array}$ & $9.90-16.83$ & $7.92-11.88$ & $9.90-14.85$ & $11.88-25.74$ & $\begin{array}{l}160.39 \\
\pm 82.53\end{array}$ & 144.82 & 23.82 & 52.44 & 74.00 \\
\hline $\begin{array}{l}\text { COD } \\
(\mathrm{mg} / \mathrm{l})\end{array}$ & $3.47-4.27$ & $3.63-3.73$ & $2.67-5.33$ & $4.27-4.80$ & $\begin{array}{l}12.79 \\
\pm 4.73\end{array}$ & 11.39 & 1.36 & 3.00 & 4.24 \\
\hline $\begin{array}{l}\text { DO } \\
(\mathrm{mg} / \mathrm{l})\end{array}$ & $1.73-2.69$ & $1.06-1.31$ & $1.55-2.90$ & $1.31-269$ & $\begin{array}{l}4.08 \\
\pm 0.89\end{array}$ & 3.73 & 0.26 & 0.56 & 0.80 \\
\hline $\begin{array}{l}\text { BOD } \\
(\mathrm{mg} / \mathrm{l})\end{array}$ & $655-829$ & $396-622$ & $380-946$ & $482-1221$ & $\begin{array}{l}1.99 \\
\pm 0.65\end{array}$ & 1.90 & 0.19 & 0.41 & 0.59 \\
\hline WQI & $\begin{array}{l}28.25-28.72 \\
\text { (Poor Quality) }\end{array}$ & $\begin{array}{l}27.50-28.63 \\
\text { (Poor Quality) }\end{array}$ & $\begin{array}{l}28.86-29.33 \\
\text { (Poor Quality) }\end{array}$ & $\begin{array}{l}28.41-28.78 \\
\text { (Poor Quality) }\end{array}$ & $\begin{array}{l}28.42 \\
\pm 0.52\end{array}$ & 28.48 & 0.15 & 0.33 & 0.46 \\
\hline
\end{tabular}

Table 5: Correlation coefficient of various physico-chemical parameters

\begin{tabular}{|c|c|c|c|c|c|c|c|c|c|c|c|c|c|}
\hline & pH & EC & TH & Acidity & TA & TDS & Cl & $\mathbf{F}$ & NO2 & SO4 & COD & DO & BOD \\
\hline pH & 1 & & & & & & & & & & & & \\
\hline EC & -0.31 & 1 & & & & & & & & & & & \\
\hline TH & -0.35 & 0.006 & 1 & & & & & & & & & & \\
\hline Acidity & -0.65 & 0.596 & 0.260 & 1 & & & & & & & & & \\
\hline TA & -0.27 & 0.698 & 0.240 & 0.187 & 1 & & & & & & & & \\
\hline TDS & -0.47 & 0.781 & 0.145 & 0.473 & 0.468 & 1 & & & & & & & \\
\hline Cl & -0.30 & 0.726 & 0.209 & 0.431 & 0.445 & 0.730 & 1 & & & & & & \\
\hline $\mathbf{F}$ & -0.56 & 0.167 & 0.309 & 0.182 & 0.329 & 0.199 & 0.248 & 1 & & & & & \\
\hline NO2 & -0.63 & 0.631 & 0.082 & 0.639 & 0.234 & 0.691 & 0.634 & 0.513 & 1 & & & & \\
\hline SO4 & -0.19 & 0.615 & -0.212 & -0.041 & 0.554 & 0.672 & 0.600 & 0.088 & 0.405 & 1 & & & \\
\hline COD & -0.009 & 0.651 & 0.119 & 0.097 & 0.433 & 0.797 & 0.655 & 0.160 & 0.542 & 0.617 & 1 & & \\
\hline DO & 0.21 & -0.152 & -0.520 & -0.537 & -0.017 & -0.054 & -0.175 & 0.378 & -0.015 & 0.143 & 0.102 & 1 & \\
\hline BOD & -0.14 & 0.010 & 0.243 & -0.219 & 0.238 & 0.209 & 0.112 & 0.792 & 0.249 & 0.038 & 0.369 & 0.668 & 1 \\
\hline
\end{tabular}

The lower amount of DO in ground water may be fitting the hand pumps to supply ground water and due to the fact that an iron pipe is being used for both mechanical and chemical processes involved 
may lead to maximum utilization of $\mathrm{O}_{2}$ and iron leading to formation of iron oxide. The low dissolved oxygen in surface water may be attributed to elevated microbial load and their metabolic activities (Meck 1996).The BOD ranged between 1.2-3.5 mg/l and was observed to be within the permissible limit prescribed by WHO.

WQI: A WQI may be defined as a rating reflecting the composite influence of the overall quality of a number of quality characteristics or water quality parameters (Yazdandoost and Katdare, 2000). The WQI of the nine sampling sites ranged between 17.98 - 26.12 (Table 1 and 3) indicating that the ground water of the Hapur district is poor quality for drinking. Without taking proper precautions this water is not suitable for drinking and other domestic activities. The WQI of different blocks of district Hapur is approximately same but the water quality of block Dhaulana is good comparatively than others blocks and the Simbhawali block is in very bad condition.

\section{Conclusion}

Analysis of ground water samples collected from different locations of Hapur district revealed that, the drinking water quality is very poor for drinking purpose. According to the analysis in some samples the water quality parameters (EC, total acidity, Total alkalinity, total hardness, TDS, sulphate, chloride, nitrate) were beyond the permissible limit as per WHO standard. This is a great need of the suitable environment management plan which may be adopted to control drinking water pollution. The ground water of this area needs some degree of treatment beforedrinking and it needs to be protected from contamination so as to prevent adverse healtheffects on human beings.

\section{Acknowledgements}

One of the author acknowledges the financial assistance from CSIR.

\section{References}

APHA. 2005. Standard methods for the examination of water and wastewater (21st ed.). Washington, DC: American Public Health Association.

Barabas, S., 1986. Monitoring natural water for drinking water quality. World Health Status Q, 39(1), 32-45.
BIS. 1998. Drinking water specifications (revised 2003). Bureau of Indian Standards.

Chaurasia, M., \& Pandey, G. C., 2007. Study of physicochemicalcharacteristics of some water ponds ofAyodhya-Faizabad. Indian Journal of Environmental Protection, 27(11), 1019-1023.

Das M, Kumar A, Mohapatra M, Murali SD., 2010 Evolution ofdrinking quality of groundwater through multivariate techniquesin urban area. Environ Monit Assess 166(14):149-157

Degremont, G., 1991. Water treatment handbook (6th ed.). Paris, France: Lavoisier Publishing.

Giridharan L, Venugopal T, Jayaprakash M.,2008 Evaluation of theseasonal variation of the geochemical parameters and qualitymanagement of the groundwater in the proximity of RiverCooum, Chennai, India. Environ Monit Assess 143(1-3):161-178

Goel, P. K.,2000 Water pollution - causes effects and control. New Delhi: New Age Int. (P) Ltd.

Jain, C. K., Bandyopadhyay, A., \&Bhadra, A.,2010. Assessment of ground water quality for drinking purpose, District Nainital, Uttarakhand, India. Environmental Monitoring and Assessment, 166, 663-676.

Jameel, A.,1998. Physico- Chemical studies in Vyakondan channel water of river Cauvery. J. of Pollution Research, 17(2): 111-114.

Krishna Kumar S, Chandrasekar N, Seralathan P, Godson PS, MageshNS., 2011 Hydro-geochemical study of shallow carbonate aquifers, Rameswaram Island, India. Environ Monit Assess.doi:10.1007/s10661-011-2249-6

Mahuya Das, Gupta, Adak and Purohit, K.M..,2003. Assessment of the water quality in Rajgangpur industrial complex - Part I: Physico-chemical parameters \& Water Quality Index. J. of Pollution Research, 22 (1): 133-138.

Meck, N.,1996. Dissolved oxygen. In Pond water chemistry. Koi Club of San Diego. http://users.venet.com/rrenshaw/H2Oquality.html. Accessed 28 July 2010.

Miller, D. W., 1985, Ground Water Quality, WileyInterscience, New York.

Mishra, P.C., Pradhan, K.C. and Patel, R.K.,2003. Quality of water for drinking \& agriculture in \& around mines in Keanjhar District, Orissa. Indian J. of Environ. Health, 45 (3): 213-220.

Ratnayaka, D. D., Brandt, M. J., \& Johnson, K. M.,2009. Chemistry, microbiology and biology ofwater-Chapter 6, Water Supply (6th ed.) 195-266. 
Water quality assessment and physicochemical parameters

SarathPrasanth SV, Magesh NS, Jitheshlal KV, Chandrasekar N,Gangadhar K.,2012 Evaluation of groundwater quality andits suitability for drinking and agricultural use in the coastalstretch of Alappuzha District, Kerala, India. Appl Water Sci.

Shankar, B. S., Balasubramanya, N., \& Reddy, M. T. M. 2008. Impact of industrialization on groundwater quality - a case study of Peenya industrial area, Bangalore, India. Environmental Monitoring and Assessment, 142, 263268.

Sharma, D. R. R., \& Rao, S. L. N. 1997. Fluoride concentration in groundwater of Vishakhapatanam, India. Bulletin of Environmental Contaminant Toxicology, 58, 241-247.
Subba Rao N 2006 Seasonal variation of groundwater quality in apart of Guntur district, Andhra Pradesh, India. Environ Geo 149:413-429

Sunitha V, Sudarsha V, Rajeswara Reddy B 2005 Hydrogeochemistryof groundwater, Gooty area, Anantapur district, Andhra Pradesh,India. Pollut Res 24(1):217-224

World Health Organization-WHO. 1997. Guidelines for drinking water quality. II ${ }^{\text {nd }}$ Edition Surveillance and Control of community supplies. Geneva, Switzerland. 3

Yazdandoost, M.Y. and Katdare, M.S. 2000. Water Quality Index of major rivers in Pune. J. of Industrial Pollution Control, 16 (2): 231-238. 